\title{
PENGARUH KONTRIBUSI KETIDAKPASTIAN TERHADAP PELAPORAN NILAI POROSITAS MENGGUNAKAN METODE GRAVIMETRI
}

\author{
Galih Setyawan $^{1}$ dan Pratiwi Indah Tri Lestari ${ }^{2}$ \\ ${ }^{1,2}$ Departemen Teknik Elektro dan Informatika, Sekolah Vokasi, Universitas Gadjah \\ Mada, Yogyakarta, Indonesia \\ Corresponding Author : galih.setyawan@ugm.ac.id.
}

\begin{abstract}
ABSTRAK
Metode gravimetri berhasil diterapkan untuk menentukan nilai porositas batu kapur. Metode tersebut dilakukan dengan menggunakan timbangan standar terkalibrasi dan gelas ukur terkalibrasi untuk menentukan volume pori dan volume total dari sampel batu kapur. Porositas ditentukan dari hasil perbandingan antara volume pori dan volume total tersebut. Nilai ketidakpastian tipe A dibandingkan dengan hasil perhitungan ketidakpastian gabungan $\left(\mathrm{U}_{\mathrm{gab}}\right)$ dengan menambahkan ketidakpastian tipe B yang bersumber dari sertifikat gelas ukur, timbangan dan temperatur. Hasilnya menunjukkan bahwa ketidakpastian tipe B menjadi penyebab utama meningkatnya nilai ketidakpastian pengukuran porositas batu kapur hingga 6\%. Namun ketidakpastian tipe B seringkali diabaikan pada pelaporan hasil pengukuran.
\end{abstract}

Kata kunci : Ketidakpastian, Porositas, Gravimetri

\begin{abstract}
Gravimetric method was successfully applied to determine the limestone porosity. The method was carried out by using calibrated standard digital scales and calibrated graduated cylinder to measure pore volume and total volume of limestone samples. The porosity was determined by comparing the pore volume and the total volume. After that, the type A uncertainty value was compared to the combined standard uncertainty value $\left(U_{g a b}\right)$ by inserting the type $B$ uncertainty value, sourced by calibrated graduated cylinder certificate, standard digital scales certificate and standard temperature certificate, to the calculation. The results showed that type $B$ uncertainty became the main caused on the increasing uncertainty value of limestone porosity up to $6 \%$. However, type B uncertainty is often overlooked in reporting of measurement results.
\end{abstract}

Keywords: Uncertainty, Porosity, Gravimetry

\section{PENDAHULUAN}

Pengukuran merupakan suatu proses membandingkan suatu besaran dengan satuan yang berlaku internasional. Pengukuran dilakukan dengan menggunakan alat ukur untuk membandingkan dimensi objek yang diukur dengan standar. Dalam pedoman evaluasi dan pelaporan ketidakpastian pengukuran oleh Komite Akreditasi Nasional (KAN) disebutkan juga mengenai pengukuran. Pengukuran adalah serangkaian operasi yang 
bertujuan untuk menetapkan nilai suatu besaran ukur (KAN, 2003). Suatu pengukuran pasti disertai dengan keraguan, apakah hasil data yang diperoleh sudah benar atau belum. Untuk menjawab keraguan itu, maka muncul ketidakpastian. Joint Committee for Guides in Metrology (JCGM) (2008), menjelaskan bahwa Ketidakpastian merupakan bentang nilai yang memungkinkan hasil ukur ada dalam rentang tersebut. Ketidakpatian pengukuran memberikan nilai lebih pada sebuah hasil pengukuran. Hasil data yang disertai nilai ketidakpastian akan lebih terpercaya. Kepercayaan sebanding dengan tingkat mutu pengukuran. Mutu pengukuran digunakan untuk mengontrol proses produksi untuk menjamin mutu suatu produk (KAN, 2008). Salah satu pengukuran yang perlu diperhatikan adalah mengenai porositas.

Porositas dapat dikatakan sebagai ukuran ruang kosong di sebuah material yang dinyatakan dalam persen. Dalam pernyataan lainnya, porositas adalah ruang yang terdapat diantara fragmen butiran yang ada pada suatu material (Sismanto, 2008, Noor, 2014). Menurut Koesoemadinata (1980), porositas dibagi dalam beberapa klasifikasi yaitu nilai porositas yang diabaikan, buruk, cukup, baik, sangat baik dan istimewa. Nilai porositas antara (20-25)\% dianggap sangat baik. Beberapa metode dapat dilakukan untuk mengukur nilai porositas. Nurwidyanto, dkk.(2005) melakukan pengukuran porositas dengan menggunakan Helium Porosimeter. Cahyani (2011) menggunakan metode geolistrik untuk mengetahui nilai resistivitas yang merupakan kebalikan dari nilai porositas. Satiyaputra (2015) melakukan perhitungan porositas dengan menggunakan metode inversi seismik.

Pengukuran porositas ini tentunya membutuhkan nilai ketidakpastian. Ketidakpastian terdiri dari ketidakpastian tipe A dan B. Tipe A berasal dari perhitungan statistik dan tipe B selain perhitungan statistik. Artinya tipe B dapat bersumber dari sertifikat instrument, pengalaman dan lain sebagainya. Pada kebanyakan pengukuran, tipe B sering tidak digunakan. Padahal tipe B juga menyumbang nilai ketidakpastian. Tujuan penelitian ini adalah ingin mengetahui seberapa besar aspek yang ditimbulkan dari kontribusi ketidakpastian tipe A dan B terhadap pelaporan nilai porositas sampel batu kapur. Metode gravimetri digunakan untuk menyelesaikan masalah dalam penelitian ini.

\section{METODE PENELITIAN}

Penelitian dilaksanakan di Laboratorium Penelitian dan Pengujian Terpadu (LPPT) Universitas Gadjah Mada Yogyakarta. Alat utama yang digunakan adalah timbangan elektronik dan gelas ukur standar yang telah dikalibrasi. Kalibrasi menurut Vocabulary of International Metrology merupakan serangkaian kegiatan yang membentuk hubungan antara nilai yang terbaca alat ukur dengan nilai-nilai yang sudah diketahui (JCGM, 2012). Timbangan elektronik yang digunakan memiliki kapasitas sebesar 210 gram dengan resolusi 0,0001 gram, sedangkan gelas ukur standar yang digunakan memiliki kapasitas $200 \mathrm{ml}$ dengan ketidakpastian $\pm 0,12 \mathrm{ml}$ (faktor cakupan bernilai 2). Selain kedua alat utama tersebut alat dan bahan lain yang digunakan adalah termohidro, pipet, sarung 
tangan, aquades dan sampel potongan batu kapur sebanyak 10 buah. Ukuran sampel yang dibuat berkisar dari 28-32 gram. Hasil porositas sampel tidak menunjukkan keseluruhan sifat porositas dimana sampel batu kapur tersebut diambil. Hal ini murni pendekatan perhitungan porositas dari segi metrologi terhadap batuan kapur. Gambar 1 menunjukkan potret dari timbangan elektronik dan gambar 2 menunjukkan sampel batu kapur yang digunakan.

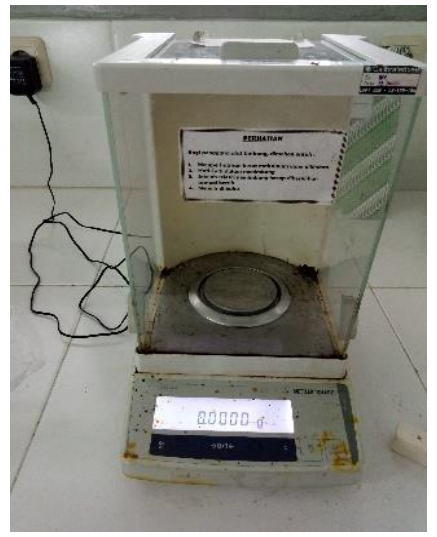

Gambar 1. Timbangan Elektronik Beresolusi 0,0001 gram

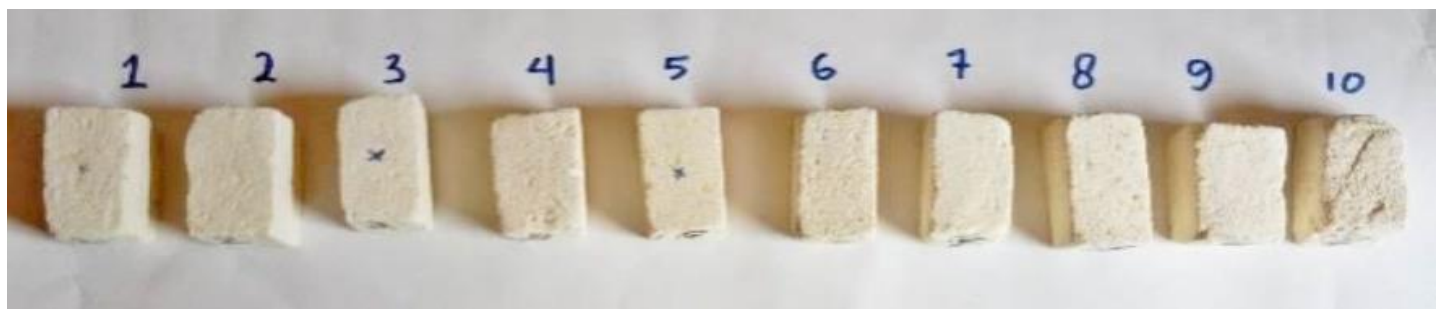

Gambar 2. Sampel Batu Kapur yang Digunakan

Penelitian diawali dengan persiapan dan pengkondisian sampel yang dilanjutkan dengan mengukur berat kering sampel $\left(W_{\text {dry }}\right)$, berat basah $\left(W_{\text {sat }}\right)$, volume pori dan volume total sampel batu kapur (V). Volume pori dapat dicari dengan menggunakan persamaan 1.Volume total ditentukan dari perubahan volume aquades pada gelas ukur dari perbandingan sebelum sampel dimasukkan dan setelah sampel batu kapur yang telah jenuh dimasukkan. Porositas dapat dihitung dengan membagi volume pori dengan volume total sampel batu kapur sesuai persamaan 2 .

$$
\text { Volume Pori }=\left(\frac{W_{\text {sat }}-W_{\text {dary }}}{\rho_{\text {fluida }}}\right)
$$




$$
\text { Porositas }=\emptyset=\frac{\frac{W_{\text {sat }}-W_{\text {diry }}}{\rho_{\text {fluida }}}}{V}
$$

Setelah didapatkan nilai porositas dari sampel batu kapur, kemudian yang dilakukan adalah mencari nilai dari ketidakpastiannya. Ketidakpastian yang diteliti adalah ketidakpastian tipe A dan B.

\section{HASIL DAN DISKUSI}

Hasil penelitian menunjukkan bahwa nilai porositas sampel batu kapur yang tertinggi adalah $24,69 \%$, sedangkan terendah sebesar 22,53\% dengan rata-rata keseluruhan sebesar $23,63 \%$. Hasil pengukuran ditunjukkan pada gambar 3. Hasil uji statistik pada tabel 1 menunjukkan bahwa nilai porositas adalah berdistribusi normal dengan nilai signifikan sebesar 0,969 .

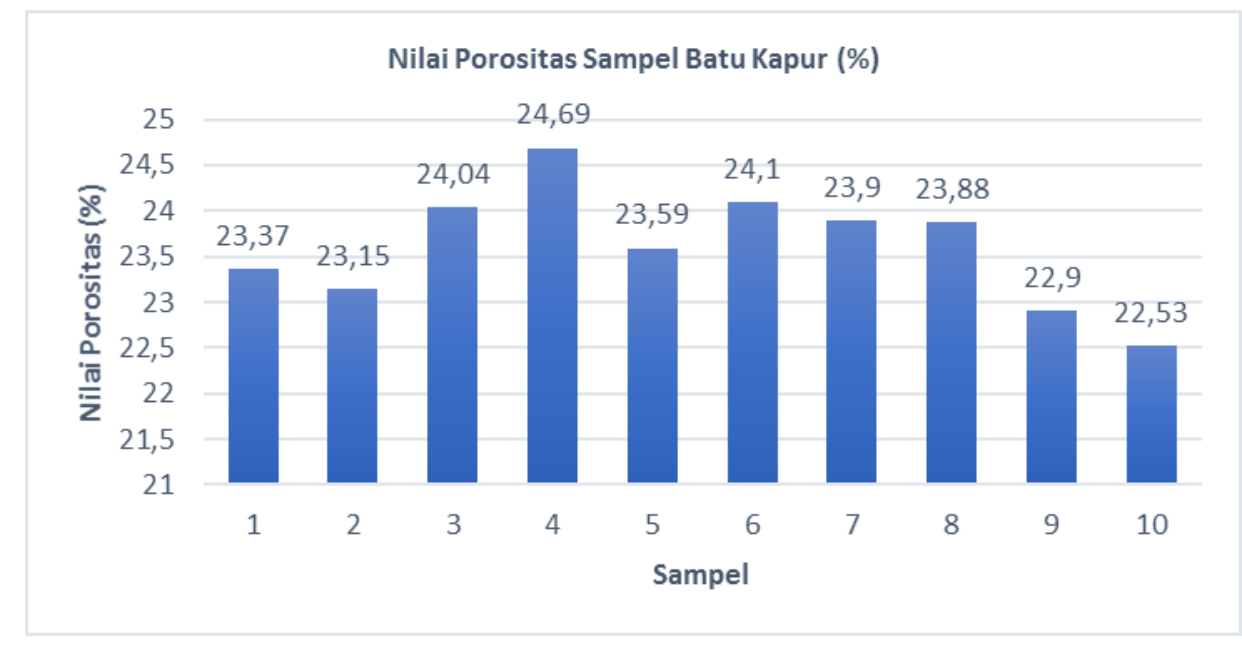

Gambar 3. Nilai Porositas sampel Batu Kapur

Tabel 1. Hasil tes normalitas

\begin{tabular}{|c|c|c|c|c|c|c|}
\hline \multirow{2}{*}{} & \multicolumn{3}{|c|}{ Kolmogorov-Smirnov } & \multicolumn{3}{c|}{ Shapiro-Wilk } \\
\cline { 2 - 8 } & Statistic & $d f$ & Sig. & Statistic & $d f$ & Sig. \\
\hline Porositas & 0.157 & 10 & 0.2 & 0.981 & 10 & 0.969 \\
\hline
\end{tabular}

Setiap nilai porositas yang ditunjukkan pada gambar 3, masing-masing nilai mempunyai nilai ketidakpastian dari tipe A dan tipe B. Tipe A dalam kasus ini berasal dari perulangan pengambilan data. Tipe B berasal dari sertifikat timbangan, sertifikat gelas ukur dan 
sertifikat ketidakpastian suhu. Salah satu contoh rincian kontribusi ketidakpastian dari sampel 1 ditunjukkan pada tabel 2.

Tabel 2. Kompenen Ketidakpastian pada Sampel 1

\begin{tabular}{|c|l|l|}
\hline No. & \multicolumn{2}{|c|}{ Komponen Ketidakpastian } \\
\hline 1 & $\mathrm{U}$ (repeat) & 0,0021 \\
\hline 2 & $\mathrm{U}$ (Sertifikat Timbangan) & 0,0004 \\
\hline 3 & $\mathrm{U}$ (Sertifikat gelas Ukur) & 0,0600 \\
\hline 4 & $\mathrm{U}$ (Temperatur) & 0,0000 \\
\hline 5 & $\mathrm{U}$ (Gabungan) & 0,0600 \\
\hline
\end{tabular}

Dapat diketahui bahwa nilai sertifikat gelas ukur lebih besar dari pada yang lain yaitu sebesar $0,06 \mathrm{ml}$, sedangkan yang terkecil adalah dari sertifikat suhu yaitu mendekati nol. Nilai ketidakpastian sebesar $0,06 \mathrm{ml}$ diperoleh dari pembagian nilai sertifikat gelas ukur dengan faktor cakupannya. Ketidakpastian B memberikan efek pada hasil pelaporan ketidakpastian gabungan. Kontribusi ketidakpastian A yang paling besar yang ditemui dalam kasus ini adalah sebesar 0,80\%. Ketidakpastian dari tipe A dalam kasus ini dipandang lebih realistis dibandingkan dengan ketidakpastian gabungan. Sebagai contoh pada sampel 1.Apabila menggunakan ketidakpastian A saja, maka hasil nilai rata-rata porositas adalah sebesar $(23,37 \pm 0,21) \%$, sedangkan bila menggunakan gabungan maka hasilnya adalah $(23,37 \pm 6,00) \%$. Hasil ketidakpastian gabungan yang didapat bila dibandingkan dengan hasil porositas maka menunjukkan nilai yang cukup besar. Hal ini ditunjukkan pada tabel 3.

Tabel 3. Nilai ketidakpastian A dan B pada semua sampel

\begin{tabular}{|c|c|c|c|}
\hline $\begin{array}{c}\text { Sampel } \\
\text { Ke }\end{array}$ & $\begin{array}{c}\text { Nilai } \\
\text { Porositas } \\
(\%)\end{array}$ & $\begin{array}{c}\text { Ketidakpastian } \\
\text { Tipe A }(\%)\end{array}$ & $\begin{array}{c}\text { Ketidakpastian } \\
\text { Gabungan }(\%)\end{array}$ \\
\hline 1 & 23,37 & 0,21 & 6,00 \\
\hline 2 & 23,25 & 0,20 & 6,00 \\
\hline 3 & 24,04 & 0,23 & 6,00 \\
\hline 4 & 24,69 & 0,21 & 6,00 \\
\hline 5 & 23,59 & 0,17 & 6,00 \\
\hline 6 & 24,10 & 0,17 & 6,00 \\
\hline 7 & 23,90 & 0,80 & 6,05 \\
\hline 8 & 23,88 & 0,23 & 6,00 \\
\hline 9 & 22,90 & 0,56 & 6,03 \\
\hline 10 & 22,53 & 0,17 & 6,00 \\
\hline
\end{tabular}




\section{KESIMPULAN}

Telah dilakukan analisis pengaruh kontribusi ketidakpastian pada hasil pelaporan nilai porositas sampel batu kapur. Dari hasil penelitian didapatkan bahwa ketidakpastian tipe B menyumbang besar pada ketidakpastian gabungan yang didapat. Nilai ketidakpastian gabungan yang didapat untuk masing-masing sampel berkisar $6,00 \%$ yang terpaut jauh dari kontribusi ketidakpastian A yang mempunyai rata-rata 0,29\%.

\section{SARAN}

Penentuan volume total yang menggunakan pembacaan gelas ukur dapat diganti dengan menggunakan timbangan yang sudah dimodifikasi. Timbangan yang sudah dimodifikasi akan menjadi alternatif untuk menghindari kontribusi nilai ketidakpastian dari sertifikat kalibrasi gelas ukur yang besar.

\section{DAFTAR PUSTAKA}

1. Cahyani, D.N., 2011, Pemetaan Deposit dan Porositas Batuan Kapur di desa Pagak kabupaten Malang Menggunakan Metode Geolistrik Konfigurasi Wenner SoundingMapping, Laporan Skripsi, Program Studi Fisika, Fakultas Matematika dan Ilmu Pengetahuan Alam, Universitas Negeri Malang, Malang.

2. JCGM, 2008, Evaluation of Measurement Data-Guide to the Expression of uncertainty in measurement, First Edition, France.

3. JCGM, 2012, International Vocabulary of Metrology-Basic and General Concepts and Associated Terms (VIM), $3^{\text {rd }}$ edition, France.

4. KAN, 2003, Pedoman Evaluasi dan Pelaporan Ketidakpastian Pengukuran, Jakarta.

5. KAN, 2008, Kebijakan mengenai ketertelusuran Pengukuran, Jakarta.

6. Koesomemadinata, R.P., 1980, Geologi Minyak dan Gas Bumi Jilid 1 dan 2, Institut Teknologi Bandung, Bandung.

7. Noor, D. 2014. Pengantar Geologi.Yogyakarta. Deepublish publisher.

8. Nurwidyanto, M.I., Noviyanti, I., Widodo,.S., 2005, Estimasi Hubungan Porositas dan Permeabilitas pada Batu Kapur (Study Kasus: Formasi Kerek, Ledok, Selorejo), Berkala Fisika, Volume 8, No.3, ISSN: 1410-9662.

9. Satiyaputra, B., 2015, Perhitungan Porositas dengan Metode Inversi Seismik dan Penentuan Daerah Reservoar Batupasir, Laporan Skripsi, Program Studi Teknik Geologi, Fakultas Teknik, Universitas Gadjah Mada, Yogyakarta.

10. Sismanto, 2008, Fisika Batuan, Laboratorium Geofisika, Fakultas Fakultas Matematika dan Ilmu Pengetahuan Alam, Universitas Gadjah Mada, Yogyakarta. 